\title{
Exploring PechaKucha in EFL learners' speaking fluency
}

\author{
Hesti Rokhaniyah ${ }^{1}$ \\ ${ }^{1}$ Department of International Relations, Humanities Faculty, \\ University of Darussalam Gontor, Ponorogo, East Java, Indonesia \\ ${ }^{1}$ hesti.r@unida.gontor.ac.id
}

Received: May 17, 2019;

Accepted: September 25, 2019;

Published: September 29, 2019

\begin{abstract}
The research aims at investigating to what extent PechaKucha optimizes English as a foreign language (EFL) learners' speaking fluency and identifying the class climate when learners implement PechaKucha. The data of the study were derived through classroom observation, pre and post-tests, field note, and interview. Constant Comparative Method was used to analyze the qualitative data while the mean score of two raters was found out to obtain the quantitative data. The result from this research indicated that the exploration of PechaKucha optimized EFL learners' speaking fluency including improving the speed of learners' speech and words per minute; increasing articulation rate; strengthening phonation time ratio; reducing the frequency of silent pause; avoiding filler words; and decreasing disfluency in spontaneous speech. The enhancement of learners' score showed from the mean score of pre-test was 65.8; post-test 1 was 73.4, and post-test 2 was 82.3. The use of PechaKucha also improved the class climate: EFL learners were involved actively to present course material and their responsibilities to work in pair increased. Considering the research findings, it is suggested that teachers and lecturers implement PechaKucha for assisting the learners to enhance their speaking fluency and creating the effective class climate.
\end{abstract}

Keywords: PechaKucha; fluency; speaking; EFL learners; speaking fluency

How to cite this paper (in APA style): Rokhaniyah, H. (2019). Exploring PechaKucha in EFL learners' speaking fluency. Journal on English as a Foreign Language, 9(2), 146-162. doi:http://dx.doi.org/10.23971 ßefl.v9i2.1326 
DOI: http://dx.doi.org/10.23971/jefl.v9i2.1326

\section{cc) (†) (อ)}

Communicative Language Teaching (CLT) is an approach to foreign languages teaching setting the concept of interaction, either process or the purpose of the learning process. Richard (2006) argued that Communicative Language Teaching in English established great enthusiasm in a language class as the goal of teaching foreign language enhanced the learners' communicative ability. Communicative Language Teaching requires both language and communication to be interdependent. Consequently, it encourages the teachers to prefer more attractive topics to the learners, gets interaction in class, and creates relevant activity emphasizing on conveying meaning than the linguistic feature. Many traditional teaching methods were replaced due to this phenomenon, for example, the grammar-translation method shifted into Communicative Language Teaching approach in teaching English.

Oral communication urges one to communicate verbal and non-verbal communication to convey a thought, feeling, and emotion. Effective spoken communication requires being able to speak either accurate or fluent to convey the meaning. Coskun (2017) assumed that fluency meant the ability to speak easily, speak in coherent, present the semantic and syntactic ability, have appropriate linguistic evidence to say, and produce creative language use. Similarly, fluency was the ability to speak rapidly, smoothly, effortless, and efficient translation of thought into language under the temporal constraint (Ramezani, Larsari, \& Kiasi, 2016). Cohen (2011) stated that fluency came from Latin; it meant "flow". The definition is similar to other languages explaining about fluency, that is fluidity. Therefore, from the characteristic mentioned above, it can be summed up that being fluent in speaking can be determined from the following aspects, namely speech rate, articulation rate, phonationtime ratio, the total number of silent pause per minute, total number of pause filler per minute, and total number of disfluencies per minute.

Speaking fluency in CLT is an essential dimension of communicative language, but some disruptions may disregard the implementation of the communicative language in the language class (Diana, 2016). The problem dealing with fluency was the learners were still confused with the grammatical form of the messages conveyed. This situation caused learners to speak hesitantly and raised a lot of pause fillers including "eemm" or "eee". Likewise, the disfluency such as restart, repetition, and prolongation also constrained 
their talk. Learners often repeated the first word as in "I uh I am not surprised at that" and revised their expression such as I mean and you know. According to the undertaken pretest, so many silent pauses had occurred when learners performed their speaking presentation. When the learners often produced the silent pauses, their expressed speech would be fragmented.

An inquiry learning approach turned the class into a high-energy learning center and set a better understanding of target language cultural knowledge. A lot of the innovative learning implemented powerpoint slides to create the presentations with creative photo albums, hyperlinked video, and attractive PechaKucha. The architect from Tokyo created PechaKucha for presentation as they got overwhelmed with awful powerpoint (Lehtonen, 2011). According to Coskun (2017), PechaKucha is made to provide a shorter presentation. The design of PechaKucha encourages the speakers to deliver the subject of a presentation in many different styles. The speakers or presenters only have 20 slides of the presentation and the slides move forward in 20

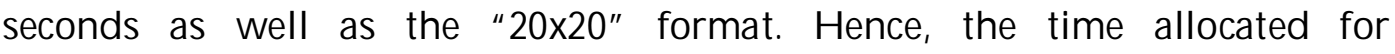
presentation is not more than 6 minutes 40 seconds (Ruiz, 2016).

Experimental results of the learners' performance carried out by Tomsett (2014) confirmed that PechaKucha was able to engage the learners in language learning as they explored their ideas, practiced their speaking skills, and enjoyed the learning process. PechaKucha project aimed to develop coherence, optimize lexical resources, avoid a grammatical problem, and make better pronunciation. PechaKucha made a presentation more interesting; moreover, it also adjusted to their needs for practical teaching. Implementing PechaKucha, the learners could change narrative into multimedia productions to enhance their presentation. PechaKucha had already been implemented in Kazakhstani students to develop language competence. The learners presented stories using photographs, video, animation, sound, music, digital images, and so forth (Tomsett, 2014). Thus, using PechaKucha to learn and to communicate stimulated the learners' understanding of the practices for building better language comprehension.

The original PechaKucha format had been altered with some variations. Edulearn Annual conference in Spain asked speakers to utilize digital presentation format PechaKucha 20x20 and their presentation developed well (Ruiz, 2016). PechaKucha format run as an alternative for paper presentation at the conference. Similarly, it anticipated the speakers to present over time and 
facilitated 5 minutes for proposing some questions. PechaKucha has proved to be an attractive and efficient way of delivering the presentation in all forums.

The use of PechaKucha as the method of assessment had been examined among third-year undergraduates by a state university in Turkey (Coskun, 2017). Having presented their ideas using PechaKucha, the learners were given feedback in detailed on their presentation performance. They had been inquired to convey their opinions on PechaKucha implementation for creative presentation as a challenge to catch up the concept, theories, models, and topics in a business major (Tomsett \& Shaw, 2014). That was very essential as the finding of the research would inform the future development of engaging classroom to support ESL learners to communicate their ideas of a business concept, theories, and method. Learners not only enjoyed the method of presentation but also improved their ability to learn about complex ideas of the subject of study they had learnt.

PechaKucha is an effective teaching aid. It was as healing for dreadful powerpoint which caused fatigue when too complex powerpoint slides were displayed (Ramos-Rincón et al., 2018). PechaKucha is a creative revision in which the EFL learners assisted the members of the class to deliver their thoughts on the given topic. Effective oral communication played a vital role in presenters and this could be transferred for learning environment as it could be emboldened as an effective method for language learning in the classroom (Rawat, 2015). To facilitate the use of the foreign language and to make sure the skill developed, PechaKucha was facilitating innovative design for learners to tackle during giving a speech (McDonald \& Derby, 2015). Due to the designed format, the powerpoint slide had to create visuals for better slideshow. As the speakers often abuse text in a slideshow, PechaKucha is the solution to give presentation assistance and improve the learners' speaking fluency.

This study tries to reveal whether and to what extent the implementation of PechaKucha enhances the learners' speaking fluency and to identify the class climate when learners implement PechaKucha in Public Speaking Class. The result of this research is expected to give clear insights about learning innovation development of English teaching and learning in EFL countries and to contribute to the enrichment of PechaKucha theories.

\section{METHOD}

The learners in the International Relations Department in one of the universities in Ponorogo Indonesia had been the subject of the research. 27 
learners in the third semester of the International Relations Department were selected; their age-range was between 19 to 20 years old. The participants had one hour and a half English class per week. Generally, the problem relevant to fluency was when learners spoke to others. They tried to make listeners understand what they said. Based on the observation in their speaking class, they got difficulties to deliver a speech or oral presentation formally. They produced a lot of the pauses and pronounced incorrectly. Regarding PechaKucha, few learners $(6 \%)$ had such an experience. Hence, exploring PechaKucha in speaking class was new to them.

The research was carried of two cycles in which each cycle was composed of 3 meetings. The research design in this study used Classroom action research. Kayaoglu (2015) asserted that action research was either research initiated to overcome a problem in the classroom. It was intended to the teacher-method classroom investigation improving the teachers' role of the effective classroom to carry out practical learning (Sandra, Andriani, Antoro, Prayekti, \& Warsito, 2012). To fit into the learners' need in the teaching-learning process, classroom action research is the proper method as it was able to observe the learners closely and analyze their needs adjusting to the techniques of teaching. It enables the researcher to do practical research intended to improve classroom learning (Hine, 2013). This research is one of the efforts of teachers or practitioners in various activities carried out to optimize the learning quality in the classroom.

The model of action research developed by Kemmis and McTaggart (1992) was utilized in this research. Kemmis and McTaggart (1992) argued that action research had four steps that were planning, action, observation, and reflection. Planning means making a plan by the action to improve the learning practice. Action is performing the planning with a certain method according to the planning. Observation means the effort to derive the data concerning the action result. Meanwhile, reflection means analyzing and interpreting the result of classroom action research; it might perform subsequent action planning to fix its lack.

Action research occurred through a dynamic and complementary process consisting of four important moments to develop an action plan to enhance what has happened, to do the plan, conduct observation about actions' effect in which they happened, reflect in this effect for setting up further planning and actions through stage succession. Both quantitative and qualitative data were used in this research. Quantitative data were derived 
from learner scores in speaking fluency from the beginning to the end of the cycle. On the other hand, qualitative data were gained from interviews, questionnaires, observations, and fieldnote. Several data sources were utilized from fieldnote, the learners; and the activities during the foreign language learning process.

The pre-test together with post-test was undertaken for quantitative data. The results of both tests conducted were then processed in the average scores and percentages. In assessing learners' fluency in speaking, the researcher applied analytic assessments as each element was evaluated separately. In contrast, words and sentences were also used to describe qualitative data for drawing brief conclusions. The technique of data analysis used in this research was the Constant Compare Method (CCM) developed by Glasser in 1980. The CCM had the following steps; compare the events that apply to each category, integrate the characteristics and categories, confine the theory, and construct the theory.

Operationally, steps are taken in this research involved pre-research, research implementation, and post research. During pre-research, the researcher identified the problem during teaching language process and confirmed the lecturer's technique together with difficulties in teaching speaking. Research implementation focused on conducting each cycle based on the procedure of action research that was planning, implementing, observing, and reflecting each procedure phase. In the planning step, the researcher made lesson plan about a certain topic, material, schedule, and instrument for observation. In implementing phase, researcher the activities based on the lesson plan. While, in the observing step, the researcher recorded significant occurrences during the teaching-learning process. The researcher also observed learners activity and noted the strength and the weakness of PechaKucha implementation. In reflecting, researcher recited and evaluated the occurrence in the teaching-learning process as a reflection of the action. The result of reflection became a basic consideration to create a plan and conduct the next cycle. Post research was the last step in the research. The researcher identified learners' opinion about the implementation of PechaKucha in speaking class.

In collecting the data, qualitative and quantitative data were used to know learners' fluency in speaking and the class climate when PechaKucha was implemented. The qualitative data collected in the study were composed of the information derived during pre-research, the process, and the results of action research implementation including observation, interview, questionnaire, and 
document analysis. While quantitative data of the research were collected through a test. The test was constructed primarily as a device to reinforce learning. Tests used as the instrument of the study included pre-test and posttest. A pre-test was conducted before the treatment. In contrast, post-test was set up at the end of the treatment.

Qualitative data were described using words and sentences to get the conclusion. They were analyzed using the Constant Comparative Method (CCM). All incidents occurred in the data were coded into as many as possible and the diverse properties were then integrated to make some senses of the meaning of the data. The rough data appearing in the observation, interview, questionnaire, and documentation analysis were selecting and simplifying to give a clearer result. After that, the data were displayed in the form of brief descriptions and tables that would be more easily understood and the final judgments of the finding were determined. Quantitative data gained from the tests were also analyzed. The mean of pre-test and post-test scores were used to analyze the teaching and learning process. It was done to know learners' fluency when PechaKucha was implemented in speaking class.

\section{FINDINGS}

All learners participating in this research had previously used traditional powerpoint presentations in the speaking classroom. Thus, they were accustomed to applying Microsoft Office PowerPoint. Learners practiced guiding principles for the format of PechaKucha presentation. The participants were pointed out and taught the definition of PechaKucha, its strengths, and also the procedure to use it (e.g., the number of slides, time for every slide, and the significance of image attachments through slides). During this course, learners were described as "PechaKucha Rubric" developed by Holliday in Coskun (2017) to familiarize them with good PK presentation features.

Two examples of PechaKucha taken from the official PechaKucha website (www.pechakucha.org) had been shown to let learners comprehend the PechaKucha convention. Learners were facilitated with a 20x20 powerpoint template. They could create 20 slides, and each slide was displayed for 20 seconds before advancing to the following slide. Thus, learners could prepare presentations for about six minutes and 40 seconds. Having received training, learners performed their presentations using PechaKucha to deliver their topics. The topic should be relevant to the research they had done to meet the subject of Public Speaking. This presentation was examined carefully by researchers to ensure they would be in line with the PechaKucha format. 
The increase in learners' speaking fluency was realized after PechaKucha was applied in learning. The findings of PechaKucha implementation were categorized into two main points as follows: PechaKucha exploration could optimize learners' speaking fluency, and PechaKucha exploration could enhance classroom climate. The improvement of learners' speaking fluency was characterized by learners could manipulate the time for speaking to reduce the frequency of pause filler, silent of pause, and disfluency produced in spontaneous speech. Likewise, learners developed speech rate, articulation, and phonation to speak concisely. PechaKucha also improved the class situation. PechaKucha facilitated 20 images or slides in which each picture or slide only displayed for 20 seconds required responsibility and sensitivity for learners to be active in the class. Learners were actively involved; learning objectives could be achieved maximally. Data obtained from field observation observations illustrated that learners continued to communicate enough due to the right method. They became aware of what the lesson was rather than minding about their business.

Field observations from the first cycle revealed that having implemented PechaKucha presentation, most learners were able to perform better at the level of fluency in speaking. The process of teaching and learning during the first meeting went as well and few learners experienced difficulties in articulation along with the ratio of the time of phonation. Teaching and learning at the second meeting was also effective. This meeting emphasized on building learners' motivation in speaking while they were overwhelmed and the courage of learners' confidence in speaking went down. The use of PechaKucha could stimulate learners' thinking to get reasons for their assumptions. This proved that the classroom environment got better enhancement than the beginning lesson. Learners defined PechaKucha implementation in speaking class improved language learning, especially fluency in speaking. PechaKucha gave important pedagogical implications for EFL learners. At the third meeting, the post-test 1 was conducted to determine the fluency of learners' speaking. Learners were required to convey their speaking performance using the PechaKucha format. They looked serious when doing post-tests 1. Having completed post-test 1, the researcher reviewed the learners' speaking performance. The score had several degradations, for example in the total number of pauses per minute. Thus, research for the next cycle should be continued.

Numerical and verbal data were gathered to observe some weaknesses occurring in the first cycle. Numerical was speaking test and verbal data were 
questionnaire and observation sheet. The questionnaires were distributed to learners while the observation form was filled out by the researcher. Data informing the attitudes of learners to the process of teaching and learning during PechaKucha implementation were represented in verbal data. There were six indicators to optimize learners' fluency including articulation rate, speech rate, phonation time ratio, silent of pause, disfluencies per minute, and pause filter. These indicators had been tested in the speaking test. The mean score for the pretest was 65.8. After the posttest 1 was conducted, there was a bit increase in learner achievement. The mean score of the posttest was 73.4. That meant the improvement was quite significant.

The first indicator was the level of speech rate. This indicator assisted learners in talking spontaneously quickly, smoothly, efficiently; the average score was 73.85. In contrast, nine learners still had low scores. Therefore, it did not reach the passing grade criteria (75). The second indicator was the level of articulation. The mean score was 71.5. That was lower than the first indicator. However, there were only four learners with low scores. The third indicator was the phonation time ratio. The results show the average learner score for this point was 73.38. That was higher than the second indicator and lower than the first indicator. On the other hand, ten learners had a low disfluency score. Learners also needed some enhancements relevant to the mean length of run, some pause fillers per minute and spontaneous disfluencies (see Table 1).

Table 1. Result average in Cycle 1

\begin{tabular}{cllllll}
\hline & \multicolumn{6}{c}{ Fluency measurement } \\
\cline { 2 - 7 } Name & $\begin{array}{l}\text { Speech } \\
\text { rate }\end{array}$ & $\begin{array}{l}\text { Articulation } \\
\text { rate }\end{array}$ & $\begin{array}{l}\text { Phonation } \\
\text { time ratio }\end{array}$ & $\begin{array}{l}\text { TN } \\
\text { silent of } \\
\text { pause }\end{array}$ & $\begin{array}{l}\text { TN of } \\
\text { pause } \\
\text { filler }\end{array}$ & $\begin{array}{l}\text { TN } \\
\text { disfluency }\end{array}$ \\
\hline Pre-Test & 66.75 & 62.84 & 65.31 & 64.52 & 65.72 & 67.83 \\
Post Test & 73.85 & 71.5 & 73.38 & 74.61 & 73.98 & 73.18 \\
\hline
\end{tabular}

Teachers, learners, and the classroom environment refer to class climate factors. The implementation of PechaKucha in the classroom climate in this cycle can be concluded not as a significant change. There were some learners not attractive and not didactic. Moreover, some of them still got indolent to perform their speaking skill. Learners also could not take part in activities planned by the researcher. In case learners did not get what they should obtain in class, they might be reluctant to ask a few questions. That made class activities a little fruitless. Based on the class climate conditions, the researcher decided to proceed second cycle and the lesson plan for the next cycle was revise as well.

Journal on English as a Foreign Language, 9(2), 146-162

Copyright (C) 2019 by JEFL, p-ISSN 2088-1657; e-ISSN 2502-6615 
Observations from Cycle 2 assumed that having had PechaKucha implementation several times, learners had less difficulty in the level of fluency. Their words were sometimes filled with pauses, yet they were able to avoid halting and fragmentary. The message contents conveyed also let the speech easy to understand. Although still hesitant, some learners spoke at normal speed while others got fast speed. PechaKucha also got learners to be more aware in expressing their argumentations. The score enhancement was also revealed in post-test of the second cycle. Learners derived 82.3 in the post test. It showed better than the first cycle average score of 73.4. Table 2 shows learners' scores improvement in Cycle 2.

Table 2. Result average in Cycle 2

\begin{tabular}{lllllll}
\hline & \multicolumn{5}{c}{ Fluency measurement } \\
\cline { 2 - 7 } Name & $\begin{array}{l}\text { Speech } \\
\text { rate }\end{array}$ & $\begin{array}{l}\text { Articulation } \\
\text { rate }\end{array}$ & $\begin{array}{l}\text { Phonation } \\
\text { time ratio }\end{array}$ & $\begin{array}{l}\mathrm{TN} \\
\text { silent of } \\
\text { pause }\end{array}$ & $\begin{array}{l}\text { TN of } \\
\text { pause } \\
\text { filler }\end{array}$ & $\begin{array}{l}\text { TN } \\
\text { disfluency }\end{array}$ \\
\hline Pre-Test & 66.75 & 62.84 & 65.31 & 64.52 & 65.72 & 67.83 \\
Post Test I & 73.85 & 71.5 & 73.38 & 74.61 & 73.98 & 73.18 \\
Post Test II & 82.54 & 83.08 & 81.53 & 82.85 & 83.46 & 80.49 \\
\hline
\end{tabular}

The second cycle also indicated positive class climate. The application of a new method was able to encourage the learners' participation in each activity. PechaKucha presentation showed 20 images or slides in which each picture or slide only displayed for 20 seconds required responsibility and sensitivity for learners to be active in the class. Learners were actively involved; learning objectives could be achieved maximally. Data obtained from field observation observations illustrated that learners continued to communicate enough due to the right method. They became aware of what the lesson was rather than minding about their business. Table 3 below shows the results of class climate improvement.

PechaKucha presentation utilized the imagery of spoken words to produce a concise presentation. The researcher introduced the fundamental of PechaKucha creation and asked them to make either a keynote or PowerPoint presentation, using 20 images. The images should be set up to tell a comprehensible explanation and every image was shown for 20 seconds. Learners were also requested to emphasize the importance of public speaking point: voice, volume, clarity, eye contact, and posture. Besides, the researcher displayed example of PechaKucha presentations to them via pechakucha.org or showed a pre-made PechaKucha presentation to the class. Learners then had 
time to think ideas/topic deeply as it was important to let them work creatively and focus on their presentation creations first. At the start of the next class, learners had their presentations on a USB and did their presentation for the class using both computer and projector. After all of the learners were finished, the class could discuss their opinions about the presentation.

Table 3. The class climate improvement in Cycle 2

\begin{tabular}{lll}
\hline \multicolumn{1}{c}{ Indicators } & \multicolumn{1}{c}{ Cycle 1 } & \multicolumn{1}{c}{ Cycle 2 } \\
\hline $\begin{array}{l}\text { EFL learners were } \\
\text { involved actively to } \\
\text { present course material }\end{array}$ & $\begin{array}{l}\text { Some learners still felt } \\
\text { indolent to show their } \\
\text { speaking performance }\end{array}$ & $\begin{array}{l}\text { The learners were } \\
\text { experientially involved } \\
\text { in an engaging activity to } \\
\text { explain the course } \\
\text { material }\end{array}$ \\
$\begin{array}{l}\text { EFL learners liked to } \\
\text { discuss the meaning of the } \\
\text { target language }\end{array}$ & $\begin{array}{l}\text { The class was so noisy } \\
\text { because of the controlled } \\
\text { activities }\end{array}$ & $\begin{array}{l}\text { The class was still noisy, } \\
\text { yet their noise was just } \\
\text { due to their curiosity to } \\
\text { learn learners' } \\
\text { responsibility increased }\end{array}$ \\
& $\begin{array}{l}\text { Most learners were } \\
\text { motivated to work in pair } \\
\text { and a classroom climate } \\
\text { developed based on the } \\
\text { social interaction among } \\
\text { learners }\end{array}$ & $\begin{array}{l}\text { The class affected } \\
\text { learners' attitude, } \\
\text { learning motive, and } \\
\text { speed which increased } \\
\text { the quality of the } \\
\text { classroom climate }\end{array}$ \\
\hline
\end{tabular}

\section{DISCUSSION}

To answer the first research question: "whether and to what extent the implementation of PechaKucha enhances the learners' speaking fluency," the result of the posttest illustrated that PechaKucha design helped learners reveal evidence to support their fluency in their presentations. Learners could propose more knowledgeable opinions with supporting evidence given. Thus, they were able to provide better alternative perspectives for their argumentations. Columbi (2017) declared that presenting and preparing for PechaKucha let learners achieve conciseness, brevity and helped them deliver a lot of the information in a short time. Learners felt that PechaKucha exposure improved their overall speaking as well as presenting skills.

To answer the second research question: "how is the class climate when learners implement PechaKucha in Public Speaking class. The result of the field note of observation demonstrated that, as shown in Table 3, the exploration of PechaKucha optimized the class climate. Learners were requested to implement PechaKucha; they could participate in a class that had been completely 
scheduled by the researcher. In this positive vibe, learners could express their fluency more confident and convey the right opinions for assumptions. These findings agree with other studies. Angelina (2019) argued that PechaKucha was acknowledged to be an effective way to provide an oral presentation and to give learners plenty of time to deliver questions. Learners became more autonomous while preparing PechaKucha. It indicated that the learners were experientially involved in the engaging activity to explain the course material. The use of PechaKucha: 20 slides with 20 seconds were stiffer but more engaging. The technique aimed to create interest in learners, make them think critically and communicate relaxed. This format focused on the idea of audience analysis, encouraged speakers to be more active toward the components of the topic, and displayed material verbally and nonverbally (Leff et al., 2011). Therefore, PechaKucha was a great method to optimize the class climate.

The most positive feedback on PechaKucha was learners were able to manipulate the time to reduce the frequency of disfluencies and pause filler made in speaking. Learners also produced more syllable units and expressed the contents of their thoughts well. Through the implementation of PechaKucha, learners derived many opportunities to fill their time by talking. Furthermore, as shown in table 2, the use of PechaKucha was beneficial to develop their English language acquisition as learners significantly improved their presentation and communication skill. This reflection confirms the finding of an earlier study that PechaKucha was acknowledged to be an effective way to eliminate fluency disorder. Learners focused on maintaining the better rate of speech and remembered to pause between sentences and words; they showed greater frequency in their presentations (Columbi, 2017).

The second positive feedback on PechaKucha was the learners' abilities relevant to score articulation, and phonation had improved as well after PechaKucha had been implemented at English speaking class. Learners' score of articulation rate enhanced from 71.5 in post-test 1 to 83.08 in post-test 2 . Likewise, learners' ability to produce a varied type of phonation also improved significantly. Their phonation scores rose from 73.38 in post-test 1 to 81.53 in post-test 2. The finding was the same as the result expressed by Nguyen (2015). It indicated that PechaKucha had many benefits for learners. The method forced learners to think critically as they should filter the information to speak on their slides. PechaKucha also helps learners improve their articulation as well as intonation due to its controlled timing and stress-timed characteristic which assisted learners to obtain natural-sounding connected speech. The limitation of 
strict time required learners to rehearsal frequently, which enhanced their speaking fluency.

PechaKucha, as used in this research was effective to control speech rate during a presentation. It was a special style of presentation which privileged short and powerful message. Using PechaKucha, learners presented as consistent as possible with the ideal rate and showed enthusiasm through vocal variety and facial expression. Nguyen (2015) argued that the focus of PechaKucha was on visual and the presenters were advised to control the speed of rate during the presentation. Presenters should be ready to present each slide once it was displayed automatically for twenty seconds. If they produced a normal speaking rate, it affected the listeners' perception of the speakers and the importance of the conveyed message.

In support of Zharkynbekova et al. (2017), presentation in PechaKucha should not be longer than 6 minutes and 4 seconds. Due to this format, the slides of power point depended on visuals rather than text heavy slides. It helped learners relax and minimize the anxiety of speaking in front of the class. Hence, learners were able to avoid a tendency to use a lot of filler words like um..uh.. while presenting to the audience. PechaKucha was one of the best characteristics as the speakers often abused text in slideshows. The visual aid and words complemented each other and the presentation had been more engaging because of the auto-advancing slides, the format, and the time constraints.

Class climate refers to the classroom environment, emotional, and social aspect in which the teachers and the learners feel in the classroom. The finding of this study reported that learners showed positive attitudes and views toward the use of PechaKucha in their speaking class. Learners showed a high level of motivation using body language expression. The slides were organized in a way and easy to understand and follow; therefore, they felt more confident to present their work, a view supported by Columbi (2017). PechaKucha not only enhanced the classroom climate but also created an advantageous condition for language learning. More concise and engaging presentation style, as well as motivating class climate, improved the learning process. Similarly, Rawat (2015) asserted that practicing speaking helped learners build confidence in talking in front of the audience and their field of knowledge. He also stated that performing oral presentation developed learners' integrated language skill as learners had written notes for their slides, read notes, spoken to the audience, and listened for questions together with feedback cues.

Journal on English as a Foreign Language, 9(2), 146-162

Copyright (C) 2019 by JEFL, p-ISSN 2088-1657; e-ISSN 2502-6615 
The type of environment created and encouraged by the teacher to let all learners participate actively in the classroom. The negative climate made interaction extremely disruptive to the learning environment; a positive class climate felt a sense of respect, safety, and welcoming (Khasiniah, 2017). It meant that class climate required the physical condition to engage learners' behavior which contributed to a positive vibe and the teacher's attitude towards learners which influenced learners' participation in the learning process. The use of PechaKucha optimized speaking performance as shown in Table 3. The researcher asked learners to review their friends' speaking performance in the post-test 2 and analyze their performance based on fluency indicators. Here, the class became a class discussion and created a democratic classroom environment. The classroom atmosphere above was beneficial for learners as it gave an equal opportunity for their contribution in class.

To gauge the possibility of PechaKucha presentation into Public Speaking subject taught in International Relations Department, the task achievement of the speaking class was served in an engaging environment which encouraged the learners to think about the topic for discussion. EFL Learners had to identify relevant visual image used, and then to speak to those images for conveying an understanding of the topic delivered. Doherty and Hilberg in Tomsett and Shaw (2014) assumed that achievement could be obtained when teachers set the classroom into diverse activity in which the learners with less capable in class would benefit most. This needed a new concept to be applied in classroom and PechaKucha was presentation format which facilitated learning activity for an individual (Tomsett \& Shaw, 2014). PechaKucha use was a beneficial presentation design to enhance learners' presentations quality (Nguyen, 2015) and to optimize learners' speaking competence (Zharkynbekova et al., 2017).

\section{CONCLUSION}

The exploration of PechaKucha can optimize the learners' speaking fluency. This increase is evidenced by mean score enhancement of post-test Cycle 1 as well as Cycle 2. Learners can manipulate speaking time; therefore, they can minimize the frequency of silent pauses, pause filter, and disfluency in spontaneous speaking. More syllable units are also produced to convey their though. Also, PechaKucha develops the classroom climate; learners' engagement to create effective learning environment gets better, the motivation and interest of learners to present material improve, their responsibility to be involved in groups to discuss problems relevant to speaking fluency enhances, and they look more confident to express their ideas during the presentation. 
PechaKucha can positively contribute to EFL learners as reflected in academic achievement.

The PechaKucha use as an innovative method of learning in the speaking class also brings new enthusiasm for learners. From a perspective on teaching and evaluating PechaKucha's presentation, many learners show sufficient creativity and artistic abilities to design their presentation. English lecturers should produce fun learning activities to facilitate learners with a lot of chance to share their thoughts and to gain skill and experience. Hence, learners can participate by volunteering asking, answering, or discussing during the class. Various techniques or methods in teaching speaking skill must be created to maintain learners' interest. For learners, PechaKucha can develop learners' language and technology skill for transforming learners' presentation. The time management for Pechakucha can be useful for learners as the presentation time constrains 20-seconds per a slide no more and no less. For other researchers, the results of this study can be an additional reference to produce a better quality of teachers' pedagogical knowledge and the teaching profession.

\section{REFERENCES}

Angelina, P. (2019). Improving Indonesian EFL students' speaking skill through PechaKucha. LLT Journal: A Journal on Language and Language Teaching, 22(1), 86-97. https://doi.org/10.1017/CBO9781107415324.004

Cohen, J. (2011). Second-language literacy instruction: five principles for effectivefluency development. The Asian EFL Journal Professional Teaching Articles, 54(2), 59-68. Retrieved from http://www.asian-efljournal.com/PTA/August-2011.pdf\#page=59

Columbi A.G. (2017). The impact of PechaKucha presentations in the assessment of a translation studies unit at the University of Western Australia. IAFOR Journal of Education, 5(3), 67-85. https://doi.org/10.22492/ije.5.3.03

Coskun, A. (2017). The Effect of pecha kucha presentations on students' English public speaking anxiety. Profile: Issues in Teachers' Professional Development, 19(1), 11-22. https://doi.org/10.15446/profile.v19n_sup1.68495

Dema, O., \& Moeller, A. K. (2012). Teaching culture in the 21st-century language classroom. Touch the World: Selected Papers from the 2012 Central States Conference on the Teaching of Foreign Languages, 75-91. Retrieved from

http://digitalcommons.unl.edu/cgi/viewcontent.cgi?article=1176\&context teachlearnfacpub

Journal on English as a Foreign Language, 9(2), 146-162

Copyright @ 2019 by JEFL, p-ISSN 2088-1657; e-ISSN 2502-6615 
Diana, S. (2016). Communicative language teaching and its misconceptions about the practice in English language teaching (ELT). Jurnal Pendidikan Bahasa Dan Sastra, 14(1), 36. https://doi.org/10.17509/bs_jpbsp.v14i1.700

GonzálezRuiz, C. (2016). Student perceptions of the use of pechakucha presentations in Spanish as a foreign language. EDULEARN16 $\begin{array}{llll}\text { Proceedings, } & 1 & \text { (July 2016), }\end{array}$ https://doi.org/10.21125/edulearn.2016.0064

Hine, G. S. C. (2013). The importance of action research in teacher education programs. Issues in Educational Research, 23(2), 151-163.

Kayaoglu, M. N. (2015). Teacher researchers in action research in a heavily centralized education system. Educational Action Research, 23(2), 140-161. https://doi.org/10.1080/09650792.2014.997260

Kemmis, S. \& McTaggart, R. (1992). The action research planner, $3^{\text {rd }}$ ed. Victoria: Deakin University Press.

Khasiniah, S. (2017). Managing disruptive behavior disruptive. Englisa Journal of Language Education and Humanities, 4(2), 79-89. https://doi.org/http://dx.doi.org/10.22373/ej.v4i2.1661

Leff, S. S., Thomas, D. E., Shapiro, E. S., Paskewich, B., Wilson, K., NecowitzHoffman, B., \& Jawad, A. F. (2011). Developing and validating a new classroom climate observation assessment tool. Journal of School Violence, 10(2), 165-184. https://doi.org/10.1080/15388220.2010.539167

Lehtonen, M. (2011). Communicating competence through pechakucha presentations. Journal of Business Communication, 48(4), 464-481. https://doi.org/10.1177/0021943611414542

McDonald, R. E., \& Derby, J. M. (2015). Active learning to improve presentation skills: the use of pecha kucha in undergraduate sales management classes. Marketing Education Review, 25(1), 21-25. https://doi.org/10.1080/10528008.2015.999593

Nguyen, H. (2015). Student perceptions of the use of PechaKucha presentations for EFL reading classes. Language Education in Asia, 6(2), 135-149. https://doi.org/10.5746/leia/15/v6/12/a5/nguyen

Ramezani, R., Larsari, E. E., \& Kiasi, M. A. (2016). The relationship between critical thinking and EFL learners' speaking ability. English Language Teaching, 9(6), 189. https://doi.org/10.5539/elt.v9n6p189

Ramos-Rincón, J. M., Sempere-Selva, T. S.-S., Romero-Nieto, M., Peris-García, J., Martínez-de la Torre, G., Harris, M., \& Fernández-Sánchez, J. (2018). Pechakucha presentations by medical students in Spain. International Journal of Medical Education, 9, 244-245. https://doi.org/10.5116/ijme.5b92.52e3 
Rawat, D. (2015). Importance of communication in teaching learning. Scholarly Research Journals for Interdisciplinary Studies, 26(4), 358-368.

Richard, J. C. (2006). Communicative language teaching in China. In Cambridge Universitiy Press. Retrieved from http://d.wanfangdata.com.cn/periodical_kzyyjs-s201110118.aspx

Sandra S. A., Andriani, D., Antoro, S. D., Prayekti, \& Warsito. (2012). Teaching and learning classroom action research at a distance in an Indonesian urban community. Excellence in Higher Education, 2(2), 114-120. https://doi.org/10.5195/ehe.2011.47

Tamura, E. T. (2006). Concepts on the methodology of teaching English. The Economic Journal of Takasaki City University of Economics, 48(3), 169-168.

Tomsett, P. M., \& Shaw, M. R. (2014). Creative classroom experience using pechakucha to encourage ESL use in undergraduate business courses: A pilot study. International Multilingual Journal of Contemporary Research, 2(2), 89-108.

Zharkynbekova, S., Zhussupova, R. F., \& Suleimenova, S. (2017). exploring PechaKucha in EFL learners' public speaking performances. 3rd International Conference on Higher Education Advances, 189-198. https://doi.org/10.4995/head17.2017.5103

\section{Author's Brief CV}

Hesti Rokhaniyah is a lecturer of International Relation Department, University of Darussalam Gontor, Ponorogo, East Java, Indonesia. She obtained her master degree in Graduate School of Teacher Training and Education from Sebelas Maret University in 2014. 